\title{
Response of Ecological Environment to Climate Change in the Source Area of the Yangtze River Based on the Observation During 2005-2015
}

\author{
Ling-Ling Song ${ }^{1}$, Qing Tian ${ }^{1 *}$, Zong-Jie $\mathbf{L i}^{2}$ \\ ${ }^{1}$ College of Forestry, Gansu Agricultural University, Lanzhou, Gansu 730070, China \\ ${ }^{2}$ College of Energy and Power Engineering, Lanzhou University of Technology, Lanzhou 730050, China
}

Received: 5 February 2021

Accepted: 27 April 2021

\begin{abstract}
Ecological environment in the source area of the Yangtze River has also undergone significant changes under the context of global climate warming. Based on the long term observation data (observation data of vegetation, soil moisture and desertification was from 2005 to 2015), desertification degree gradually decreased, vegetation height increased, the change of coverage was weak, above ground biomass significantly decreased and soil moisture significantly decreased after 2009 thorough analysis of correlation and annual change of wind erosion, wind deposition, vegetation situations and soil moisture from 2005 to 2015 . So atmospheric precipitation wasn't a directly specially important factor to ecological environment in the source region of Yangtze river in the context of climate warming and wetting and atmospheric precipitation was indirectly affecting the ecological environment in the source region of the Yangtze river. Rain could reduce environmental temperature and temperature was also an important factor for vegetation growth. Atmospheric precipitation didn't play an important role in wind erosion and wind deposition in the study area. Precipitation increase could reduce height and coverage of vegetation in the source region of Yangtze river. And above ground biomass of vegetation might increase with the precipitation increase and climate becoming warm and wet. Atmospheric precipitation only directly affected soil moisture under the context of climate warming and wetting.
\end{abstract}

Keywords: climate change, ecological environment change, response, the source area of the Yangtze River

\section{Introduction}

Qinghai Tibet Plateau is known as 'the roof of the world' and 'the third pole of the earth', which is the

*e-mail: tianqing622@126.com

'River source' of China and Asia [1-3]. At the same time, it is the strategic base of water resources security in china [4-5]. Qinghai Tibet Plateau plays a significant barrier action for ecological security of China and Asia [6-8]. Qinghai Tibet Plateau is the one of the sensitive regions for climate change to global change and it is hot area for global change research, too. In recent years, climate especially atmospheric precipitation of Qinghai 
Tibet plateau occur significant changes in the context of global climate change [1, 3, 9-12].

Climate change has a series of impacts on water resources, hydrological system, species migration and grain yield. The fifth assessment report of IPCC points out that the global surface temperature is expected to exceed $1.5^{\circ} \mathrm{C}$ from 1850 to 1900 at the end of the $21^{\text {st }}$ century[13]. In the future, extreme events are likely to occur more frequently and last longer. China is more seriously affected by global warming, which is higher than the global average in the same period. As a sensitive area of climate change and ecological environment, the source region of the Yangtze River is affected by both climate change and human activities, especially since the implementation of the ecological protection project in the early $21^{\text {st }}$ century [13-14].

With the continuous change of climate, the water shortage in the original water resource- poor areas will be more serious, and many water quality will also change greatly in this process [15]. Therefore, the amount of water resources available for use is reduced, which leads to the failure of its function to be effectively played. With the influence of human activities, a series of changes have taken place in surface processes, such as land use change, urbanization process, conversion of farmland to forest, which lead to the change of water cycle elements in time and space, and the change of water resources [12-13].

Climate change drives the change of water cycle on the global scale and causes different responses on the regional scale. Meanwhile, the change of surface processes on the regional scale further causes the change of water resources or runoff on the regional and watershed scales [16]. As a matter of fact, the process of multi-scale interaction of surface water, surface water and permafrost is the result of multi-scale interaction Water circulation in the surrounding area. The shortage of water resources will fundamentally affect agricultural output, cause food crisis and threaten human survival and development. Moreover, climate change is a new and important factor that aggravates the global water shortage and food crisis. As time goes on, its impact may be more widespread and far-reaching. To deal with the global water shortage and food crisis, people need to pay more attention to the factors of climate change, further clarify its impact mechanism, degree and scope, and take effective measures to reduce carbon emissions, curb the trend of global warming, and restore the global water cycle [17]. This is the fundamental way and longterm plan to solve the double crisis of global water resources and food.

The source region of Yangtze river is an area that the most complex ecological environment and the most concentrated area of biodiversity [5, 18-19]. Meanwhile, the source region of Yangtze river owns the largest wetland area and the most rivers in high elevation. The unique location and fragile ecological environment of the source region of Yangtze river faces great challenges under the double influences from global warming and human activities [3, 5, 20]. Since 1980s, with the rapid development of China western economy and population continuous growth the fragile alpine ecosystem began to suffer more and more pressure from human activities [21-26]. However, under the background of the global climate change, What is the effect of atmospheric precipitation in the source region of the Yangtze River on the ecological environment of the region? How about the relationship between desertification situations, vegetation growth and soil moisture and atmospheric environment? These urgent questions need to be solved further.

\section{Material and Methods}

\section{Study Area}

The source region of the Yangtze River $\left(90^{\circ} 43^{\prime} \sim 96^{\circ} 45^{\prime} \mathrm{E}-32^{\circ} 30^{\prime} \sim 35^{\circ} 35^{\prime} \mathrm{N}\right)$ is located in the area above the hydrographic station of Zhimenda (Fig. 1). The Basin have 5 major river: Chumaer river, Tuotuo river, Gaerqu river, Buqu river and Dangqu river, respectively. The average altitude of this area is over $4500 \mathrm{~m}$, and many peaks are over $5500 \mathrm{~m}$, which is a Typical Alpine frozen soil area. The source region of the Yangtze River is one of the main distribution areas of the plateau wetland on the Qinghai Tibet Plateau. The glacier area accounted for more than $89 \%$ of the entire Sanjiang source region, meltwater runoff accounted for more than $25 \%$ of the source region of the Yangtze river. Climate is dry and cold. Solar radiation is very strong and the frost free period is very short. The main vegetation types in the study area is alpine meadow and steppe.

\section{Observation}

Budongquan, Wudaoliang and Tuotuohe as the observation point, soil moisture, wind erosion and vegetation situations in the study area were systematically observed from 2005 to 2015. Soil moisture was measured mainly by soil tube profile moisture meter. This instrument can directly measure soil moisture. It can simultaneously measure the soil parameters at different depths and upload them to the data center through the GPRS (GSM) network. Vegetation coverage is mainly measured by Vegetation Coverage Observation System. Surface vegetation coverage photogrammetry system includes portable vegetation coverage photogrammeter and automatic calculation system of surface vegetation coverage. One part is the hardware part. Even with the portable vegetation coverage photogrammeter, its function is to take vertical photographs to obtain vegetation coverage images. Another part is the PCOVER software. Its function is to process the acquired image and calculate the vegetation coverage automatically. The height of plant measured by steel tape. Desertification is 


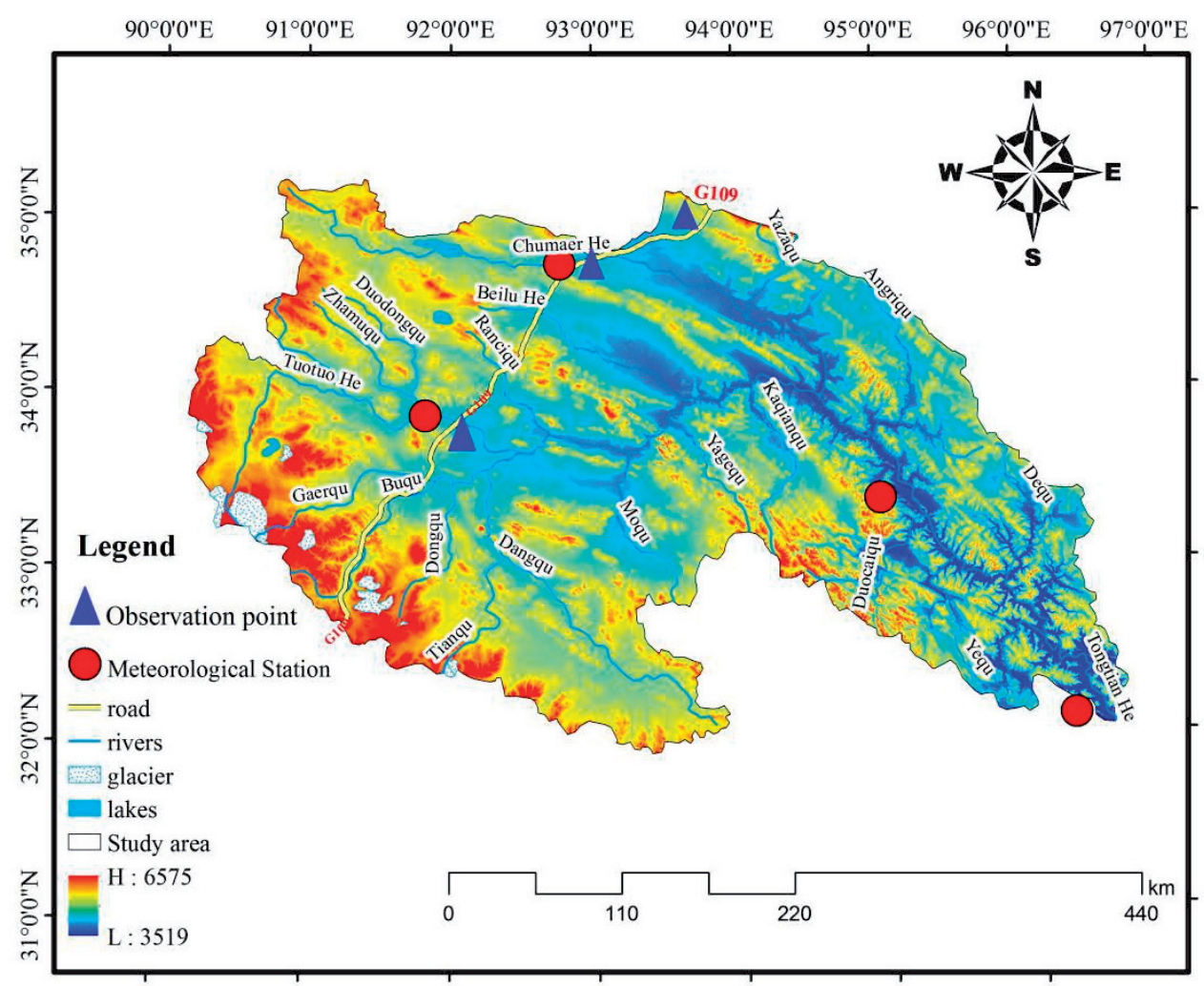

Fig. 1. Sketch map showing the source region of the Yangtze River.

mainly monitored by the Wind Erosion Observation System. The sampling period of each collection point is 15 seconds or 30 seconds. Usually the sampling period is from 15 seconds to 2 hours.

Firstly, this paper analyzed meteorological data of Yushu, Qunalai, Wudaoliang and Tuotuohe Meteorological Station (Fig. 1) from 1959 to 2015 to make sure climate change situation. Then, systematic analysis the variation of desertification situations, vegetation growth and soil moisture and the relationship between desertification situations, vegetation growth and soil moisture and atmospheric environment in Budongquan, Wudaoliang and Tuotuohe station in the source region of Yangtze River from 2005 to 2016 (Fig. 1). Finally, to explore the effect of atmospheric precipitation in the source region of the Yangtze River on the ecological environment of this region. The results are also helpful for further providing reference data for the whole Sanjiang source protection area and the whole Qinghai Tibet Plateau and providing scientific basis for effectively prevent and control the ecological environment problems. Meanwhile, provide scientific basis for further research in the future.

\section{Results and Discussion}

\section{Analysis of Climate Change}

In recent years, greenhouse gases increasing and heat balance of Earth's surface have caused global climate change. So climate change has an important influence on the ecological environment and hydrological cycle and runoff formation [6]. Through analysis of meteorological factors, such as temperature, precipitation and wind speed from 1959 to 2015, the results showed that average temperature showed a significant increasing trend $\left(\mathrm{R}^{2}=0.5343\right)$, the other say was that the temperature of source region of Yangtze river showed a significant warming trend in the past 56 years (Fig. 2). And variation range of annual average temperature was $0.331^{\circ} \mathrm{C} / 10 \mathrm{a}$. Precipitation showed an increasing trend $\left(\mathrm{R}^{2}=0.1872\right)$, with variation range was $14.4 \mathrm{~mm} / 10 \mathrm{a}$ (Fig. 2). In short, climate of the source region of Yangtze river was becoming warmer and wetter. Extensive research suggests that temperature of Qinghai Tibet Plateau was lower from the end of 19 century to 1920s. Temperature of Qinghai Tibet Plateau begun to rise since 1920s. As a result of water vapor transfer and water content showed significant seasonal variation and geographical distribution, precipitation of Qinghai Tibet Plateau showed an increasing trend but not significant. Recent studies on climate change of the source region of Yangtze river have convincingly argued that temperature and precipitation of the source region of Yangtze river showed an increasing trend. This is mainly due to ocean evaporation and enhanced land evapotranspiration, land-atmospheric water cycle accelerated in the context of climate warming. However, what is the role of atmospheric precipitation in the source region of the Yangtze River under the background of climate 

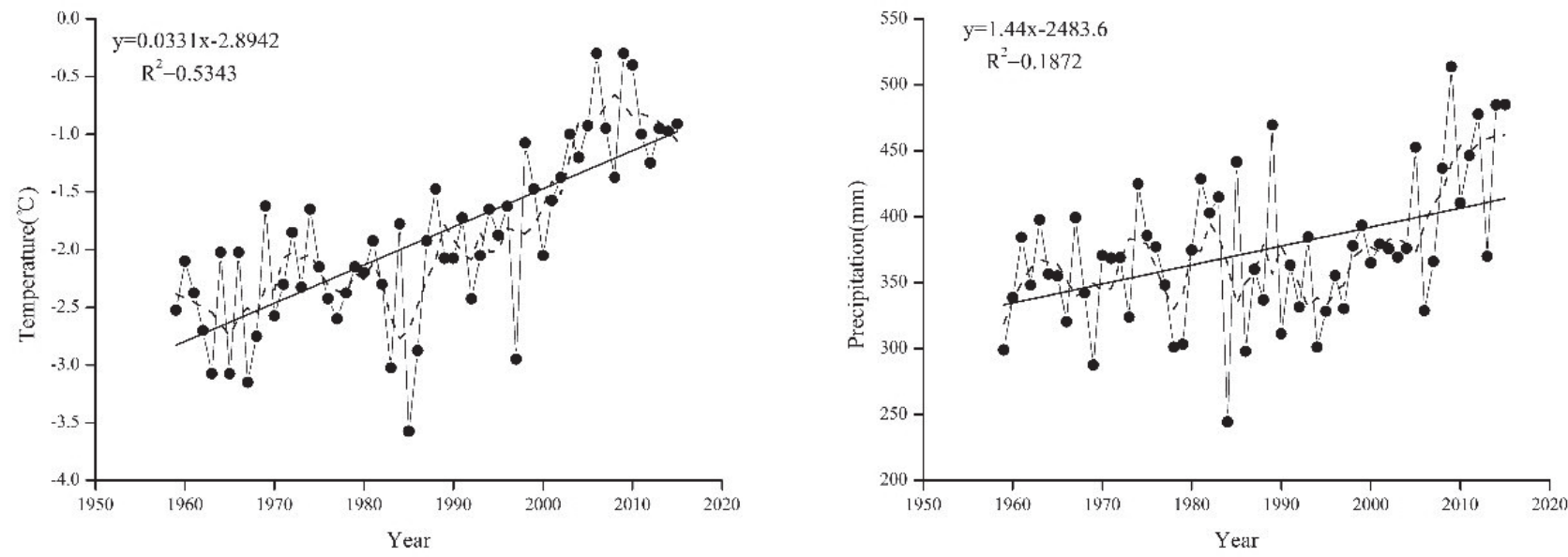

Fig. 2. Climate change of the source region of Yangtze river from 1959 to 2015.

warming and warming? What is the environmental significance? This requires further analysis in the following parts.

\section{Desertification}

Desertification is one of the most important problems in the source region of the Yangtze river. Desertification of the source region of the Yangtze river not only affects ecological security of the source region of Yangtze river, but also affects sustainable development in the whole Yangtze river basin [24]. Through analysis of wind deposition and wind erosion in the source region of Yangtze river from 2005 to
2015, the results showed that wind deposition showed a significant decreasing trend $\left(\mathrm{R}^{2}=0.5932\right)$ from 2005 to 2015 (Fig. 3) and the wind erosion also showed a significant decreasing trend $\left(\mathrm{R}^{2}=0.5102\right)$ year by year (Fig. 3). But the decreasing trend of wind deposition was higher than wind erosion. Average wind deposition was $0.17 \mathrm{~cm}$ and average wind erosion value was $0.18 \mathrm{~cm}$ from 2005 to 2015 in the source region of Yangtze river. The highest value of wind deposition was $0.22 \mathrm{~cm}$, which appeared in 2005 and 2008. Highest value of average wind erosion appeared in 2005, with the value was $0.24 \mathrm{~cm}$. The lowest value of average wind deposition and wind erosion were all happened in 2012. But the lowest average wind deposition was

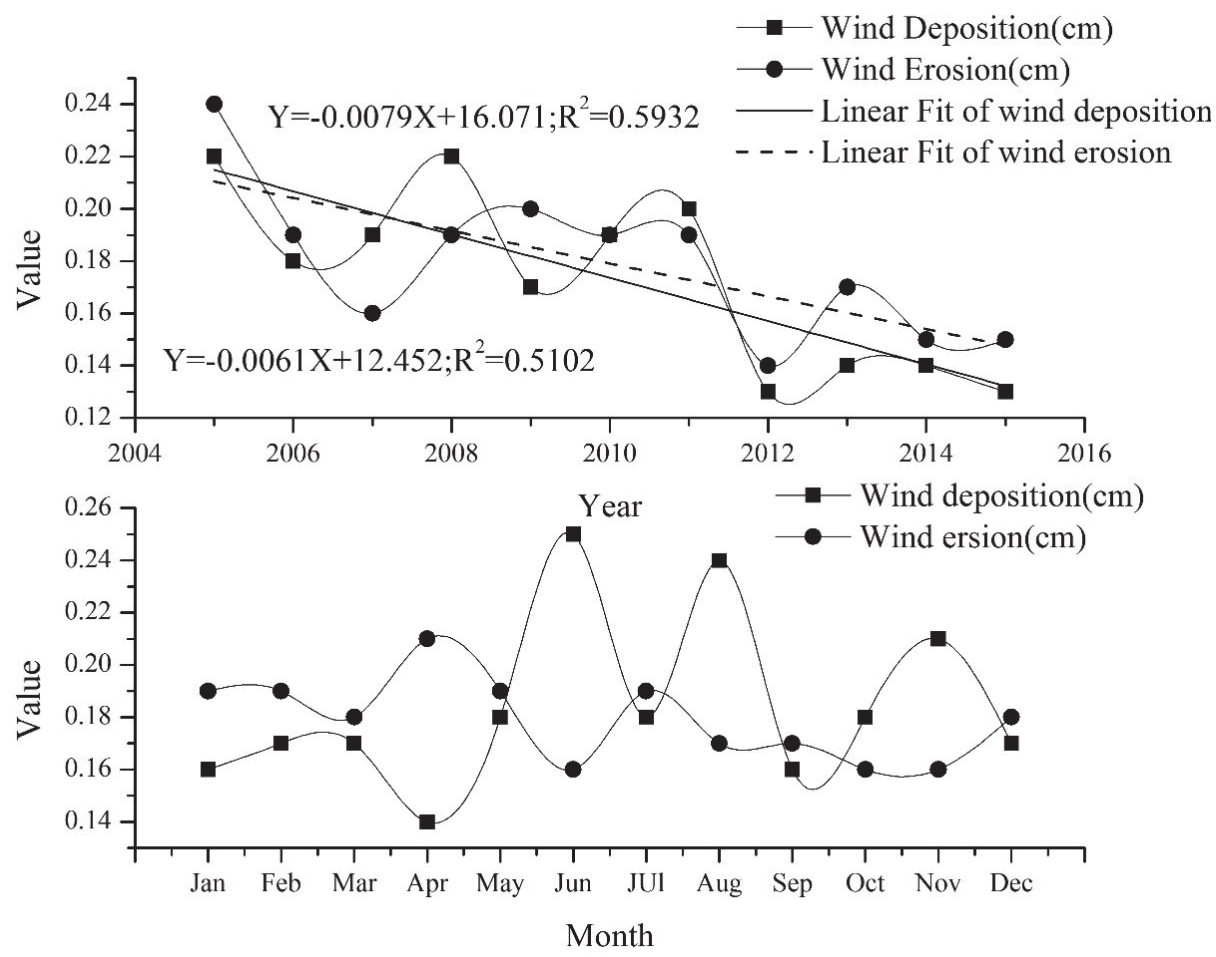

Fig. 3. Desertification situation of the source region of Yangtze river from 2005 to 2015. 


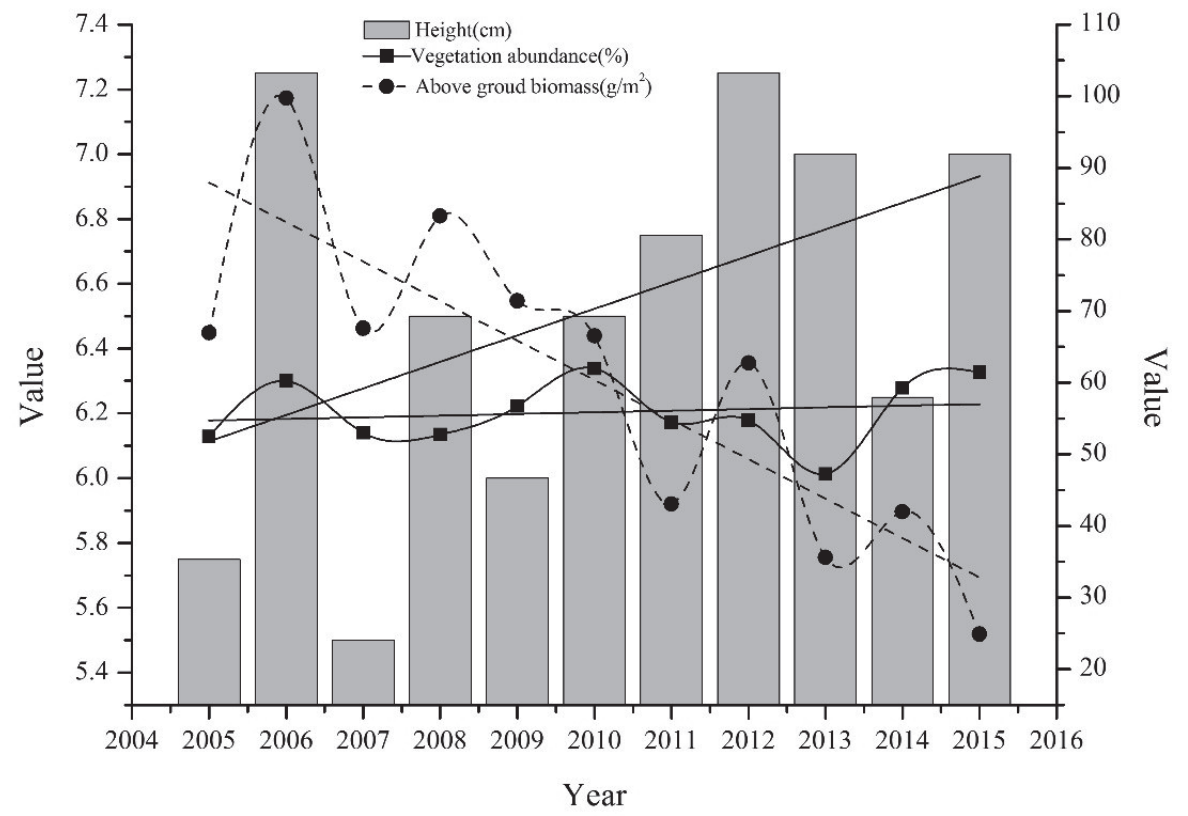

Fig. 4. Vegetation situation of the source region of Yangtze river from 2005 to 2015.

$0.13 \mathrm{~cm}$ and the wind erosion was $0.14 \mathrm{~cm}$. From seasonal variation analysis, May was an important month for desertification in the source region of Yangtze river. Before May, the value of wind erosion was greater than that of wind deposition, but it was opposite after May. This further suggested that there was obvious seasonal changes for desertification in study area. The highest of wind deposition showed in June $(0.25 \mathrm{~cm})$ and lowest in April $(0.14 \mathrm{~cm})$. However, The highest of wind erosion showed in April $(0.21 \mathrm{~cm})$ and lowest in June, October, November $(0.16 \mathrm{~cm})$. This showed that wind erosion and wind production might show

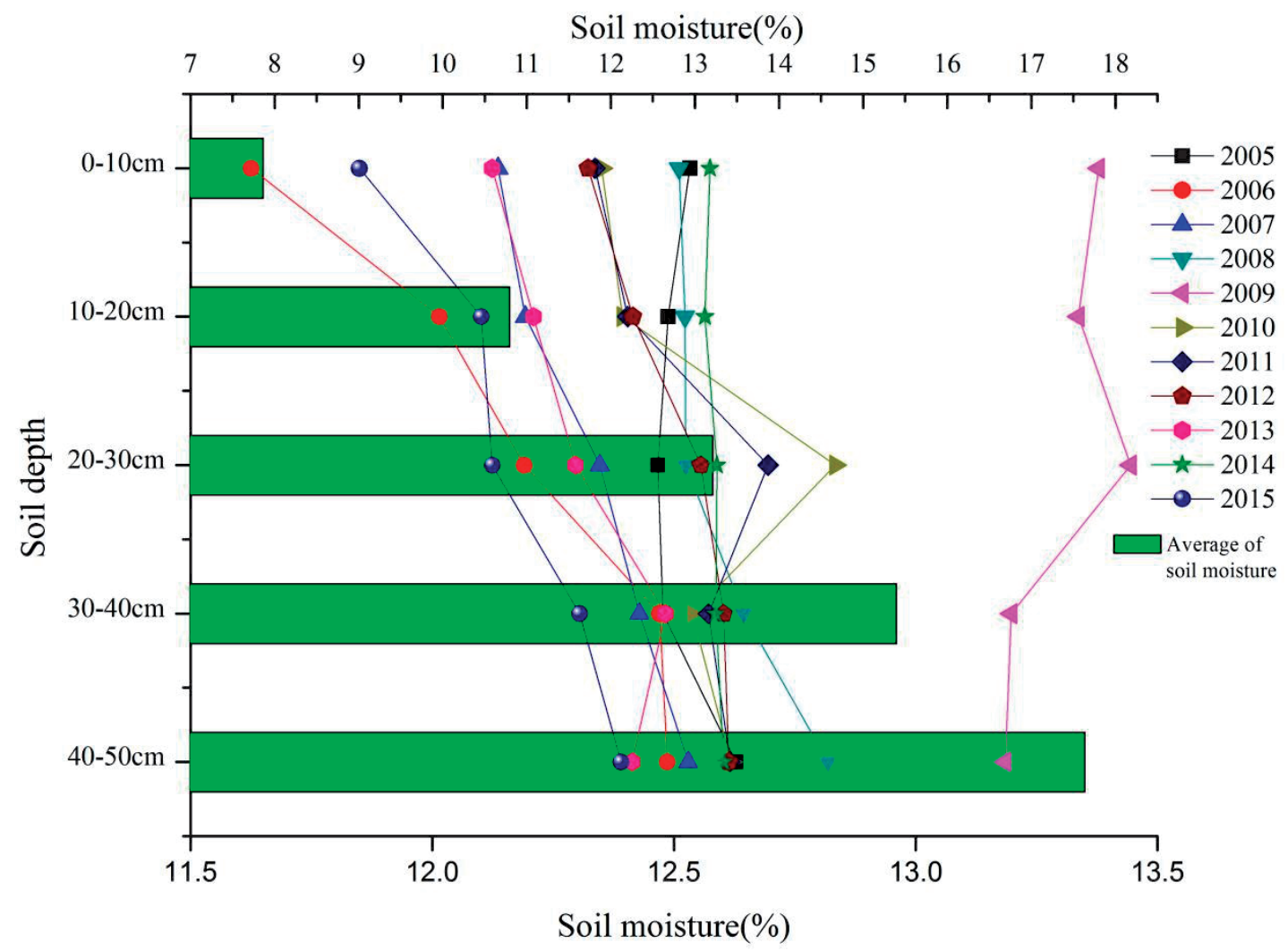

Fig. 5. Variation of soil moisture in the source region of Yangtze river from 2005 to 2015. 


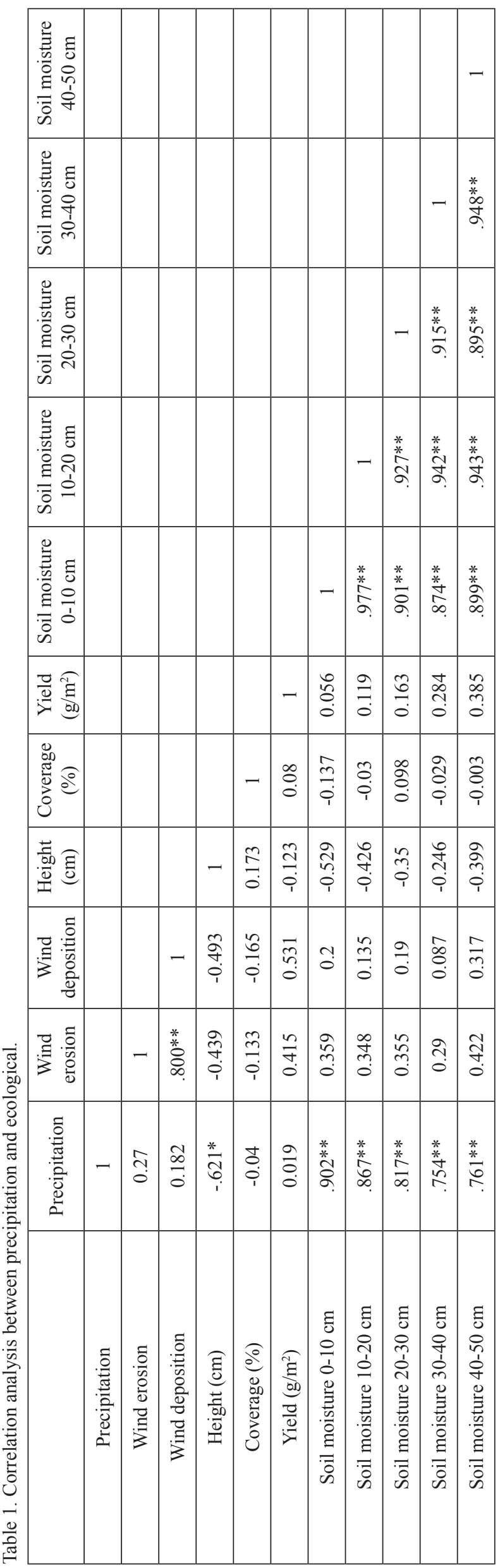

negative correlation. With the increasing precipitation, rising of temperature and decreasing of wind speed, wind deposition and wind erosion showed significant decreasing trend in the context of climate warming and wetting.

\section{Analysis of Surface Vegetation}

Alpine meadow is one of the most vegetation types in the source region of Yangtze river [7 27]. Alpine meadow dominated by low temperature and cold plants faced more serious ecological threat under the influence from global climate change [28-30]. Certainly, the influence from climate to grassland vegetation was long term, slow and large area [31-34]. The height of vegetation in the source region of Yangtze river showed a significant increasing trend $\left(\mathrm{R}^{2}=0.207\right)$ from 2005 to 2015 (Fig. 4). And the coverage also showed an increasing trend, but not significant $\left(\mathrm{R}^{2}=0.028\right)$. But the above ground biomass of vegetation showed a significant decreasing trend $\left(\mathrm{R}^{2}=0.6903\right)$ from 2005 to 2015. Height of vegetation increased, coverage also increased and above ground biomass decreased in the context of climate warming and wetting in the source region of Yangtze river. Owing to precipitation and temperature increased made the height and coverage of vegetation increased, too. However, the above ground biomass showed decreasing trend, which indicated that precipitation and warming time wasn't conducive to improve vegetation above ground biomass. This mainly duo to severe water shortage in the green period and lack temperature in mature period of forage grass. Certainly, this point was also a result for climate change.

\section{Analysis of Soil Moisture}

Soil moisture is key factor for soil-plants-atmosphere linking. It is the carrier of soil system nutrient cycling and flowing, too [18]. Soil moisture not only directly affects soil characteristic and plant growth, but also indirectly affects plant distribution and microclimate change to some degree. Take the annual change as the point of view, soil moisture in 2009 was a special node, because of soil moisture in 2009 was the largest. And soil moisture showed an increasing trend from 2005 to 2009, but decreased from 2009 to 2016 (Fig. 5). Average soil moisture increased with the increase of soil depth (Fig. 5). The order of average soil moisture for $0-10 \mathrm{~cm}$, $10-20 \mathrm{~cm}, 20-30 \mathrm{~cm}, 30-40 \mathrm{~cm}$ and $40-50 \mathrm{~cm}$ was $40-50 \mathrm{~cm}>30-40 \mathrm{~cm}>20-30 \mathrm{~cm}>10-20 \mathrm{~cm}>0-10 \mathrm{~cm}$, with the mean was $13.26 \%, 12.90 \%, 12.78 \%, 12.06 \%$ and $11.58 \%$, respectively. Meanwhile, soil moisture for all years (from 2005 to 2015) showed an increasing trend from $0 \mathrm{~cm}$ to $50 \mathrm{~cm}$ except soil moisture in 2009,2010 and 2011. Soil moisture in the source region of Yangtze river showed increasing first and then decreasing trend from 2005 to 2015 with the climate warming and wetting. 


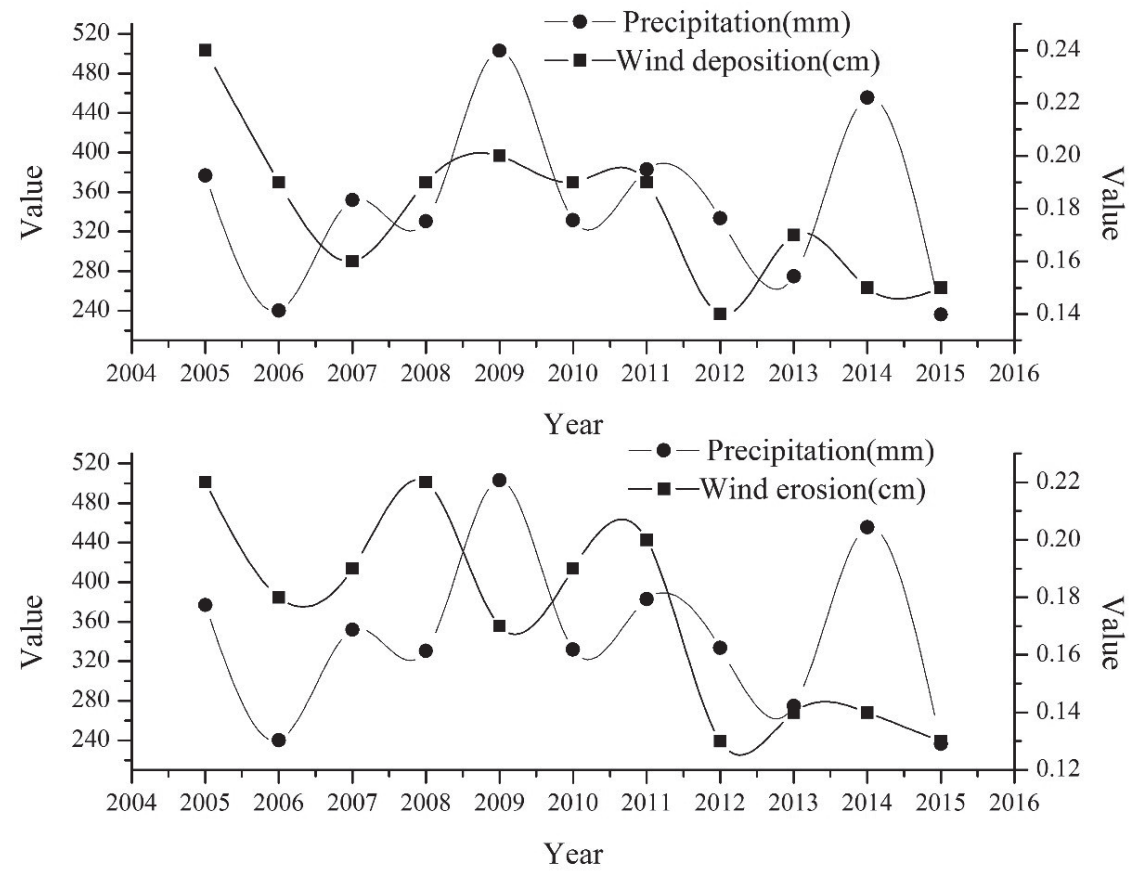

Fig. 6. Relationship between atmospheric precipitation and desertification.

Relationship between Atmospheric Precipitation and Desertification

Climate change is an important factor for desertification. Desertification is closely related to arid climate [35]. Drought and windy, especially wind season and dry season happens in the same time is main climate condition for desertification development [35-36]. Through correlation analysis and annual variation, there was a positive correlation between

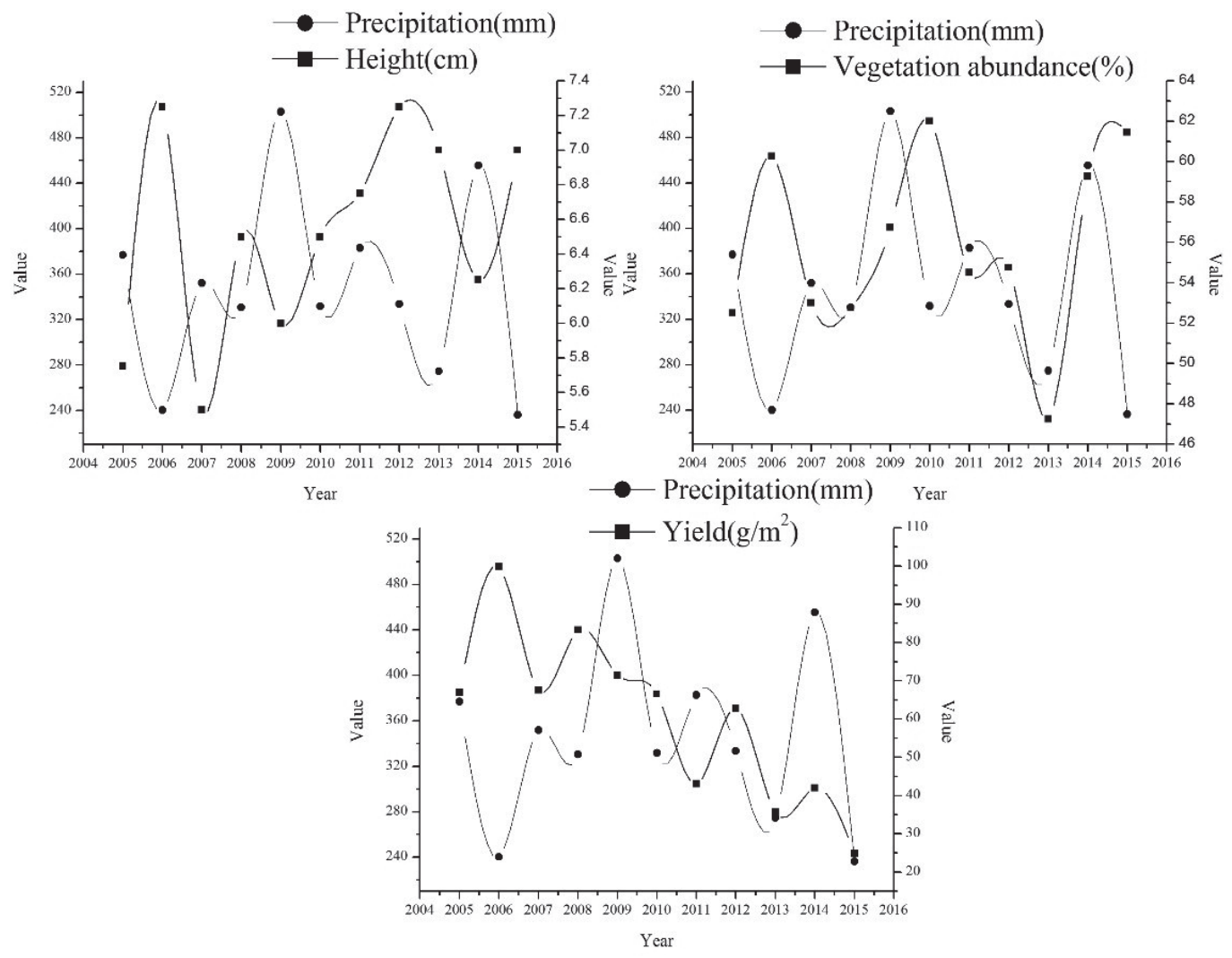

Fig. 7. Relationship between atmospheric precipitation and surface vegetation. 


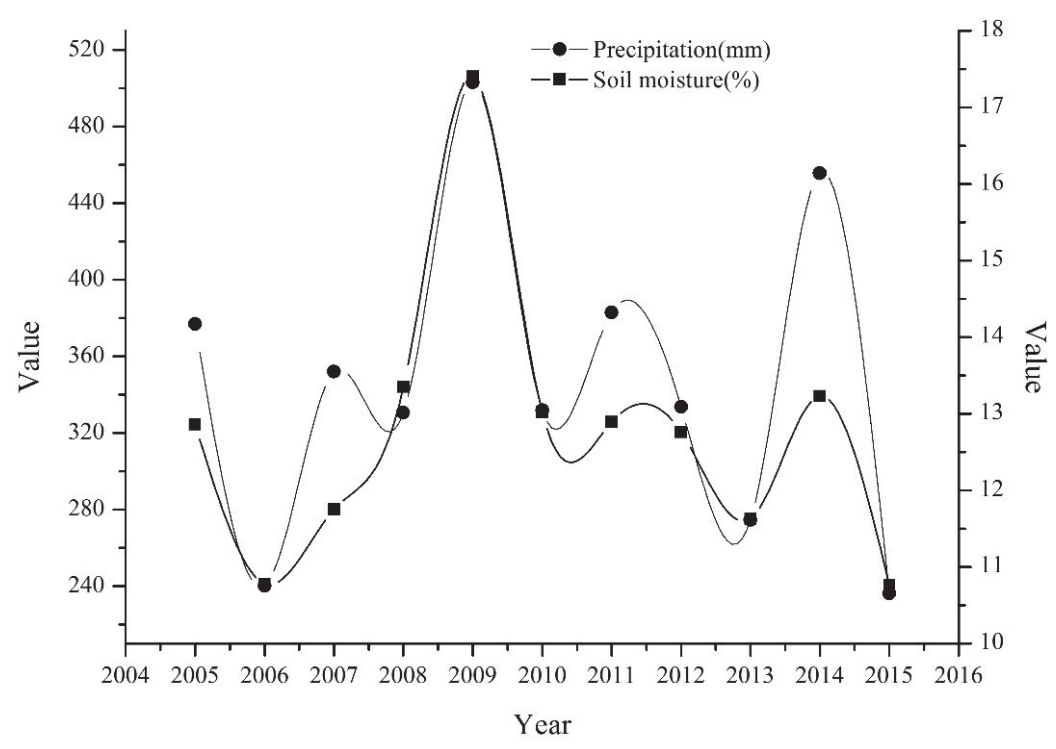

Fig. 8. Relationship between atmospheric precipitation and soil moisture.

precipitation and wind erosion (Fig. 6), but the significance was not high, the correlation coefficient was 0.27 (Table 1). As the same with wind erosion, there was also positive correlation between wind deposition and precipitation (Fig. 6), the significance was not high, the correlation coefficient was 0.182 (Table 1). In general, more precipitation could make plants grow vigorously, that is to say, it can indirectly prevent the spread of desertification. But in the source region of Yangtze river there was positive correlation between precipitation and wind erosion and deposition, which indicated that precipitation in study area couldn't effectively prevent wind erosion and wind deposition. The main reason was that the alpine meadow vegetation recovery in the Qinghai Tibet Plateau was very long and sufficient precipitation couldn't meet the rapid restoration of vegetation. Atmospheric precipitation didn't play an important role in wind erosion and wind deposition in study area in the context of climate warming and wetting.

\section{Relationship between Atmospheric Precipitation and Surface Vegetation}

Climate change is the decisive factor for vegetation growth and precipitation change is main factor for affecting ecological environment change [37-38]. Through correlation analysis and annual variation, there was a significant negative correlation between precipitation and vegetation height (Fig. 7), with the correlation coefficient was 0.621 (Table 1). There was a negative correlation between precipitation and vegetation coverage, but significance was not high and the correlation coefficient was 0.04 (Table 1). However, there was positive correlation between precipitation and vegetation coverage from 2012 to 2015 (Fig. 7). There was a positive correlation between precipitation and above ground biomass, but significance also was not high and correlation coefficient was 0.019 (Table 1). Vegetation height showed an increasing trend from 2005 to 2015 (Fig. 4). This indicated that climate factors were beneficial to vegetation height. But negative correlation between height and precipitation. On the one hand, because annual average temperature was below $0^{\circ} \mathrm{C}$ and there was a large proportion of snowfall in the annual precipitation. So precipitation wasn't an especially important factor to vegetation height in the source region of Yangtze river in the context of climate warming and wetting; On the other hand, rain could reduce environmental temperature and temperature was also important factor for vegetation growth in the source region of Yangtze river. In a word, precipitation increasing could reduce height and coverage of vegetation in the source region of Yangtze river in the context of climate warming and wetting. And above ground biomass of vegetation might increase with the precipitation increasing and climate becoming warm and wet.

\section{Relationship between Atmospheric Precipitation and Soil Moisture}

There was a very significant positive correlation between precipitation and soil moisture, and the correlation coefficients of soil horizon water and precipitation was $0.902(0-10 \mathrm{~cm}), 0.867 \quad(10-20$ $\mathrm{cm}), 0.817(20-30 \mathrm{~cm}), 0.754(30-40 \mathrm{~cm})$ and 0.761 $(40-50 \mathrm{~cm})$, respectively (Table 1$)$. The variation trend of soil moisture was similar to the change trend of precipitation (Fig. 8) from 2005 to 2015 in the source region of Yangtze river. Atmospheric precipitation directly affected soil moisture and the variation trend of soil moisture is basically consistent with the trend of precipitation. Soil moisture played an important role 
in vegetation growth and preventing wind erosion and wind deposition in the source region of Yangtze river in the context of climate warming and wetting.

\section{Conclusions}

The influence of atmospheric precipitation on ecological environment in the source area of the Yangtze River has also undergone significant changes in the context of global climate warming and wetting. Desertification degree gradually decreased, vegetation height increased, the change of coverage was weak, above ground biomass significantly decreased and soil moisture significantly decreased after 2009 thorough analysis of correlation and annual change of wind erosion, wind deposition, vegetation situations and soil moisture from 2005 to 2015 . The pitched terrain of the source region of the Yangtze River was high. Himalaya Range and the Tanggula Mountain stopped the India Ocean warm wet flow direct pass from south to north. So the climate of the Yangtze River was a typical continental climate of plateau. Because of annual average temperature was below $0^{\circ} \mathrm{C}$ and there was a large proportion of snowfall in the annual precipitation. So precipitation wasn't an especially important factor to ecological environment in the source region of Yangtze river in the context of climate warming and wetting. Rain could reduce environmental temperature and temperature was also important factor for vegetation growth in the source region of Yangtze river. Atmospheric precipitation directly affected soil moisture in the context of climate warming and wetting. Atmospheric precipitation didn't play an important role in wind erosion and wind deposition in study area. Precipitation increasing could reduce height and coverage of vegetation in the source region of Yangtze river. And yield of vegetation might increase with the precipitation increasing and climate becoming warm and wet.

\section{Acknowledgements}

This study was supported by the National Nature Science Foundation of China (42007426; 42077187), the Open Foundation of State Key Laboratory of Frozen Soil Engineering (SKLESE202011). the 'Western Light' -Key Laboratory Cooperative Research CrossTeam Project of Chinese Academy of Sciences, the Second Tibetan Plateau Scientific Expedition and Research Program (STEP, Grant No. 2019QZKK0405), National 'Plan of Ten Thousand People' Youth Top Talent Project, National Key R\&D Program of China (SQ2019YFC050024-01), Key talent project of Gansu Province (2020), Innovative Groups in Gansu Province (2020). We greatly appreciate suggestions from anonymous referees for the improvement of our paper. Thanks also to the editorial staff.

\section{Conflict of Interest}

The authors declare no conflict of interest.

\section{References}

1. ZHANG G.S., SHI X.H., LI D.L., WANG Q.C., DAI S. Climate change in Tuotuohe area at the headwaters of Yangtze River. Journal of Glaclology and Geocryology, 28 (5), 678, 2006 [In Chinese].

2. YAO T., THOMPSON L., YANG W., YU W., GAO Y., GUO X., PU J. Different glacier status with atmospheric circulations in Tibetan Plateau and surroundings. Nature Climate Change, 2 (9), 663, 2012.

3. QIN D.H. Assessment on environment of western China(Vol.1.Beijing, Science press, 54-67, 2002 [In Chinese].

4. QI D.M., LI Y.Q., CHEN Y.R., ZHAO X., \& ZHOU C.Y. The variation characteristics and causes analysis of the runoff in the source region of the Yangtze River under the background of climate change. Journal of Glaclology and Geoccryology, 37 (4), 1075, 2015 [In Chinese].

5. SONG L., TIAN Q., LI Z. Has Wind Erosion in the Source Region of the Yangtze River Been Strengthened? Polish Journal of Environmental Studies, 29 (2), 1351, 2020.

6. YAO T.D., LIU X.D., WANG N.L. The question of the range of climate change on the Qinghai Tibetan Plateau[J]. Chinese Science Bulletin, 45 (1), 98, 2000 [In Chinese].

7. YANG Z., OUYANG H., ZHANG X., XU X., ZHOU C., YANG W. Spatial variability of soil moisture at typical alpine meadow and steppe sites in the Qinghai-Tibetan Plateau permafrost region. Environmental Earth Sciences, 63 (3), 477, 2011.

8. ZHANG F. Recent stepwise sediment flux increase with climate change in the tuotuo river in the central tibetan plateau. Science Bulletin, 65 ( 5), 410, 2020.

9. KLEIN J.A., HARTE J., ZHAO X.Q. Experimental warming causes large and rapid species loss, dampened by simulated grazing, on the Tibetan Plateau. Ecology Letters, 7 (12), 1170, 2004.

10. SHEN W., ZOU C., LIU D., OUYANG Y., ZHANG H., YANG C., LIN N. Climate-forced ecological changes over the Tibetan Plateau. Cold Regions Science and Technology, 114, 27, 2015.

11. PANDEY R., BARDSLEY D.K. Social-ecological vulnerability to climate change in the Nepali Himalaya. Applied Geography, 64, 74, 2015.

12. AN R., WANG H.L., FENG X.Z., WU H., WANG Z., WANG Y. Monitoring rangeland degradation using a novel local npp scaling based scheme over the "threeriver headwaters" region, hinterland of the qinghai-tibetan plateau. Quaternary International, 444, 97, 2017.

13. IPCC, 2013. Climate change: The physical science basis contribution of working group I to the fifth assessment report of the Intergovernmental Panel on Climate Change. Cambridge, UK and New York, NY: Cambridge University Press, 2013.

14. SERKAN G.A., FRANK A.W. Integrated basin management: water and food policy options for turkey. Ecological Economics, 68 (10), 2666, 2009.

15. FAN X., ZHAO L., HE D. Land use changes and its driving factors in a coastal zone. Polish Journal of Environmental Studies, 29 (2), 1143, 2019. 
16. DENG M., MENG X., LI Z., LY V Y., LEI H., ZHAO L. Responses of soil moisture to regional climate change over the three rivers source region on the tibetan plateau. International Journal of Climatology, 40 (4), 1, 2019.

17. FENG A., LI Y., GAO J., WU S., FENG A. The determinants of streamflow variability and variation in three-river source of china: climate change or ecological restoration?. Environmental Earth Sciences, 76 (20), 696, 2017.

18. LIANG E., SHAO X., QIN N. Tree-ring based summer temperature reconstruction for the source region of the Yangtze River on the Tibetan Plateau. Global and Planetary Change, 61 (3), 313, 2008.

19. YU G.A., BRIERLEY G., HUANG H.Q., WANG Z., BLUE B., MA Y. An environmental gradient of vegetative controls upon channel planform in the source region of the Yangtze and Yellow Rivers. Catena, 119, 143, 2014.

20. OCHOA-HUESO R., MUNZI S., ALONSO R., ARRONIZ-CRESPO M., AVILA A., BERMEJO V., DECARVALHO R.C. Ecological impacts of atmospheric pollution and interactions with climate change in terrestrial ecosystems of the Mediterranean Basin: Current research and future directions. Environmental Pollution, 227, 194, 2017.

21. WANG G.X., CHENG G.D. Eco-environmental changes and causative analysis in the source regions of the Yangtze and Yellow Rivers, China. The Environmentalist, 20 (3), 221, 2000.

22. ZHOU H., ZHAO X., TANG Y., GU S., ZHOU L. Alpine grassland degradation and its control in the source region of the Yangtze and Yellow Rivers, China. Grassland Science, 51 (3), 191, 2005.

23. YANG J., DING Y., CHEN R. Climatic causes of ecological and environmental variations in the source regions of the Yangtze and Yellow Rivers of China. Environmental Geology, 53 (1), 113, 2007.

24. LU J.F., DONG Z.B., HU G.Y., SONG X., WEI Z.H. Desert dynamics monitoring by RS and its driving factors in source region of Yangtze river. Journal of Desert Research, 30 (3), 510, 2010 [In Chinese].

25. SUN W., SONG X., MU X., GAO P., WANG F., \& ZHAO G. Spatiotemporal vegetation cover variations associated with climate change and ecological restoration in the Loess Plateau. Agricultural and Forest Meteorology, 209, 87, 2015.

26. MARTINEZ-CRUZ A.L., JUAREZ-TORRES M., GUERRERO S. Assessing Impacts From Climate Change on Local Social-ecological Systems in Contexts Where Information is Lacking: An Expert Elicitation in the Bolivian Altiplano. Ecological Economics, 137, 70, 2017.
27. LI Z.X., FENG Q., XIAO Y. G., YAN G., YAN H. P., WANG T.T., HAN C.T. The evolution and environmental significance of glaciochemistry during the ablation period in the north of Tibetan Plateau, China. Quaternary International, 374, 93, 2015.

28. NAEEM S., THOMPSON L.J., LAWLETR S.P., LAWTON J.H., WOODFIN R.M. Declining biodiversity can alter the performance of ecosystems. Nature, 368 (6473), 734, 1994.

29. LOREAU M., NAEEM S., INCHAUSTI P., BENGTSSON J., GRIME J. P., HECTOR A., TILMAN D. Biodiversity and ecosystem functioning: current knowledge and future challenges. science, 294 (5543), 804, 2001.

30. WANG J., HE G., FANG H., HAN Y. Climate change impacts on the topography and ecological environment of the wetlands in the middle reaches of the yarlung zangbobrahmaputra river. Journal of Hydrology, 590, 125419, 2020.

31. TILMAN D., REICH P.B., KNOPS J.M. Biodiversity and ecosystem stability in a decade-long grassland experiment. Nature, 441 (7093), 629, 2006.

32. LI D., XU E., ZHANG H. Influence of ecological land change on wind erosion prevention service in arid area of northwest china from 1990 to 2015. Ecological Indicators, 117, 106686, 2020.

33. KANNAN S.M., SUDALAIMANI K. Spatial Time Dependent Reliability Analysis of Carbonation with Climate Change. Polish Journal of Environmental Studies, 29 (6), 4123, 2020.

34. LI R., LI Q., ZHANG J., LIU Z., PAN L., HUANG K., ZHANG L. Effects of Organic Mulch on Soil Moisture and Nutrients in Karst Area of Southwest China. Polish Journal of Environmental Studies, 29 (6), 4161, 2020.

35. CHEN S., LI X., WU T., XUE K., MORGAN C.L.S. Soil thermal regime alteration under experimental warming in permafrost regions of the central tibetan plateau. Geoderma, 372, 2020.

36. ZHAO Q., XU S., TANG Q., LU X., WANG S., JI X., DING S. Relationships between Soil Nutrients and Plant Diversity in Riparian Woodlands Along the Middle and Lower Reaches of the Yellow River, China. Polish Journal of Environmental Studies, 29 (3), 2481, 2020.

37. ZHANG W., WANG L., XIANG F., QIN W., JIANG W. Vegetation dynamics and the relations with climate change at multiple time scales in the yangtze river and yellow river basin, China. Ecological Indicators, 110, 105892, 2019.

38. XIA C., LIU G., CHEN K., HU Y., ZHOU J., LIU Y., MEI J. Stable Isotope Characteristics for Precipitation Events and Their Responses to Moisture and Environmental Changes During the Summer Monsoon Period in Southwestern China. Polish Journal of Environmental Studies, 29 (3), 2429, 2020. 